\title{
Research on Capital Structure Optimization of Listed Companies in "One Belt and One Road"
}

\author{
LUO Xue-ting \\ College of Accounting \\ Heilongjiang Bayi Agricultural University \\ Daqing, China \\ lxtadmin@163.com
}

\author{
WANG Yong-de \\ College of Accounting \\ Heilongjiang Bayi Agricultural University \\ Daqing, China \\ 124306706@qq.com
}

\begin{abstract}
Based on the data of "One Belt One Road" concept stocks listed companies in 2013 and 2014,through the "backward" multiple regression analysis, this paper takes the asset-liability ratio, current liabilities ratio and long-term debt ratio as a measure of capital structure indicators to optimize the capital structure of the model analysis for the listed companies. The results show that asset-liability ratio is negatively related to the profitability and asset management capabilities for "One Belt One Road" concept stocks listed companies, asset-liability ratio and current debt ratio is negatively related to the debt paying ability, asset-liability ratio and long-term debt ratio are positively related to the value of guarantee, long-term debt ratio is positively related to firm size, and current liabilities are positively related to growth. And the paper proposes the following suggestions for optimizing the capital structure of the listed companies: Improve asset utilization efficiency; increase debt ratio, and give fully use of financial leverage; enhance growth through the issue convertible bonds.
\end{abstract}

Keywords-"One Belt And One Road"; Listed company; capital structure

\section{INTRODUCTION}

Capital structure refers to the composition of various capitals and its proportional relationship, whose essence is an interest distribution pattern of the property right subject behind various funds interdependence, interaction and mutual generated. This pattern of benefit allocation affects the financing costs, market value, governance structure and the stability for the company's overall economic. Due to the different environment of each industry and listed company, the optimal capital structure model applicable to all industries and companies is not objective. Therefore, listed companies should consider the relevant factors and the appropriate methods to determine the optimal capital structure. In March 2015, with the formal landing of "One Belt and One Road", as one of the most important participants, capital market can bring great opportunities and challenges for the listed companies along the way. Through the study of the optimal capital structure for "One Belt and One Road" concept stocks listed companies (hereinafter referred to as "OBOR" listed companies), it is of great significance to optimize the capital structure of listed companies, allocate the proportion of debt capital rationally, make scientific financial decision, realize the goal of maximizing enterprise value and aid the implementation of

Fund Project: Heilongjiang Bayi Agricultural University Innovative Research Projects for Graduate Students: Study on the Optimal Capital Structure and Performance of Listed Companies in the Strategy of "One Belt and One Road"
"OBOR" strategy.

The modern capital structure theory began with the MM theory of Merton Miller and Fran-co Modigliani (1958), after being supplemented and amended, which eventually formed a Miller market equilibrium model involving income tax. Based on the comprehensive discussion of MM theory, the western scholars put forward two theoretical systems: One is trade-off theory based on Scott (1976) and DeAngelo (1980), the other is Pecking Order Theory being accepted widely. Charalambakis E. C.and Psychoyios D. (2012) compares the effects of firm size, asset tangible, corporate profitability, growth opportunities and other factors on the capital structure of listed companies in the United States and Britain. XING Tian-cai, YUAN Ye (2013) finds that the company profitability, non-interest tax credit and capital structure is negatively correlated. SONG Chuan-fen (2015) finds that the share of equity and claims, not only shows that the company's capital structure also shows that the company's control power.

Compared with foreign countries, research on capital structure in China aims for all listed companies in domestic mostly or a certain industry or regional, and whose indicators reflecting the capital structure are more single. At the same time, a great deal of research on the "OBOR" is explained impact on China and the world economy from a macro perspective. This paper is devoted to the study of the optimal capital structure of "listed companies along the OBOR", which is beneficial to achieve the goal of value maximization and sustainable development for the listed companies.

\section{HYPOTHESIS}

\section{A. Hypothesis 1: The capital structure is negatively related to profitability}

The Return on Equity is the most effective one to reflect the company's ability to use capital for creating profits in all the indicators that reflect the company's profitability. According to the Optimal Order Financing theory of Mydrs and Majluf (1984), the company prefers to take the undistributed profit as a source of investment, Bond and stock financing are considered only when necessary, So the profitability of enterprises can generate a large number of after-tax profits, the internal accumulation of a large degree of work can meet the needs of expanding the funding to reproduction for enterprises, and relatively, the dependence on debt funds is lower, while showing lower financial leverage. 


\section{B. Hypothesis 2: The capital structure is negatively correlated with solvency.}

This paper uses the current ratio to reflect solvency. The company's short-term solvency is stronger, the debt ratio is usually lower, and with strong long-term solvency, such a company's financial risk is lower in general

\section{Hypothesis 3: Capital structure is positively related to asset management capacity}

The asset management capability is an important aspect of assessing the company's operational capacity. This paper uses the total asset turnover rate as a measure. The stronger the company gets, the higher the efficiency of asset management becomes, the stronger the ability to resist risk becomes, so that the company has the ability to borrow funds to expand the operation, which can have more liabilities.

\section{Hypothesis 4: Capital structure is positively related to asset guarantee value}

This article takes fixed assets as collateral assets. If the proportion of assets that can be used for security is increased, the degree of credit will be increased, and thus more liabilities may be obtained. Both Asymmetric information and agency cost theory all show that the improvement of guarantee value for tangible asset can reduce the creditor's credit risk caused by information disadvantage.

\section{E. Hypothesis 5: Capital structure is positively related to firm size}

This paper uses the total assets to reflect the size of the company. Based on the trade-off theory, large companies tend to diversify their operations, with more stable cash flow, and most of which use debt tax shields.

\section{F. Hypothesis 6: Capital structure is positively related to firm growth}

The company with high growth whose development prospects are good in general is usually reluctant to issue new shares, so that avoid diluting control power and income for the old shareholders.

\section{DESIGN}

\section{A. Research objects and data sources}

The paper takes sample companies of the concept stocks along the "OBOR" issued by China Securities Index Corporation as the object of study. As the strategy of "OBOR" is put forward in 2013, the study chooses the financial data of the sample company in 2013-2014 and deletes ST and S companies, and finally selects listed companies along the "OBOR" with 30 as the research samples.

\section{B. Variable settings}

TABLE I. VARIABLE DEFINITIONS

\begin{tabular}{|c|c|c|c|c|}
\hline Variable & $\begin{array}{c}\text { Index } \\
\text { classification }\end{array}$ & $\begin{array}{c}\text { Variable } \\
\text { code }\end{array}$ & Variable name & Variable definitions \\
\hline \multirow{3}{*}{$\begin{array}{l}\text { Explained } \\
\text { variable }\end{array}$} & \multirow{3}{*}{ Capital Structure } & Y1 & debt to assets ratio & $\begin{array}{c}\text { Total liabilities / total } \\
\text { assets }\end{array}$ \\
\hline & & Y2 & Current liabilities ratio & $\begin{array}{c}\text { Current liabilities / } \\
\text { total assets }\end{array}$ \\
\hline & & Y3 & Long - term debt ratio & $\begin{array}{c}\text { Long-term } \\
\text { liabilities/total assets }\end{array}$ \\
\hline \multirow{5}{*}{$\begin{array}{l}\text { Explanatory } \\
\text { variables }\end{array}$} & Profitability & $\mathrm{X} 1$ & Return On Equity ratio & $\begin{array}{c}\text { Net profit / average net } \\
\text { assets }\end{array}$ \\
\hline & Solvency & $\mathrm{X} 2$ & current ratio & $\begin{array}{c}\text { Total assets / total } \\
\text { liabilities }\end{array}$ \\
\hline & $\begin{array}{c}\text { Asset } \\
\text { management } \\
\text { capacity }\end{array}$ & X3 & $\begin{array}{l}\text { Total Asset Turnover } \\
\text { Ratio }\end{array}$ & $\begin{array}{c}\text { prime operating } \\
\text { revenue/ average total } \\
\text { assets }\end{array}$ \\
\hline & Guarantee value & $\mathrm{X} 4$ & fixed assets ratio & $\begin{array}{l}\text { Fixed assets / total } \\
\text { assets }\end{array}$ \\
\hline & Enterprise scale & $\mathrm{X} 5$ & Total assets & $\begin{array}{c}\text { The absolute value of } \\
\text { the total assets }\end{array}$ \\
\hline
\end{tabular}

Explained variable: the capital structure is the ratio of the total liabilities to the total capital for the company, which is also being known as the financial leverage. It has different meanings for different types of debt. Based on the study of Xiao Zuo-ping (2004), this paper uses three kinds of leverage ratios to measure the capital structure according to the different maturity of the debt: Firstly, debt to assets ratio. Secondly, current liabilities ratio. Thirdly, Long-term debt ratio. Since about two-thirds of the shares in the Chinese stock market are non-tradable shares and the market value can't be measured, the debt ratio of listed companies is still calculated using the carrying amount.

Explanatory variables: this paper chooses six explanatory variables: the principle of selecting explanatory variables is based on the existing research results and theoretical analysis, combined with the study hypothesis, and then selects the more significant factors for capital structure, taking into account the feasibility of financial data.

\section{The establishment of a basic multiple regression model}

On the basis of the above analysis, we establish the following multiple linear regression model:

$Y_{1}=\beta_{0}+\beta_{1} \chi_{1}+\beta_{2} \chi_{2}+\beta_{3} \chi_{3}+\beta_{4} \chi_{4}+\beta_{5} \chi_{5}+\beta_{6} \chi_{6}+\varepsilon$
$Y_{2}=\beta_{0}+\beta_{1} \chi_{1}+\beta_{2} \chi_{2}+\beta_{3} \chi_{3}+\beta_{4} \chi_{4}+\beta_{5} \chi_{5}+\beta_{6} \chi_{6}+\varepsilon$
$Y_{3}=\beta_{0}+\beta_{1} \chi_{1}+\beta_{2} \chi_{2}+\beta_{3} \chi_{3}+\beta_{4} \chi_{4}+\beta_{5} \chi_{5}+\beta_{6} \chi_{6}+\varepsilon$

Among them, where $\beta_{0}$ is a constant, $\beta_{1} \sim \beta_{6}$ is the regression coefficient, and $\varepsilon$ is a random disturbance term.

\section{EMPIRICAL ANALYSIS}

\section{A. "Backward" Regression Model Analysis}

In this study, we use the stepwise "backward" linear regression to select the optimal capital structure model. The possible models are as follows: 


\section{A PRESS}

TABLE II. Y1 MODEL SUMMARY ${ }^{\mathrm{E}}$

\begin{tabular}{|c|c|c|c|c|c|}
\hline Model & $\boldsymbol{R}$ & $\boldsymbol{R}$ Square & $\begin{array}{c}\text { Adjust the R } \\
\text { Square }\end{array}$ & $\begin{array}{c}\text { Standard estimation } \\
\text { error }\end{array}$ & $\begin{array}{c}\text { Durbin- } \\
\text { Watson }\end{array}$ \\
\hline 1 & $.827^{\mathrm{a}}$ & .685 & .602 & 11.423921947 & \\
\hline 2 & $.824^{\mathrm{b}}$ & .679 & .612 & 11.279546011 & \\
\hline 3 & $.819^{\mathrm{c}}$ & .671 & .619 & 11.185160276 & \\
\hline 4 & $.810^{\mathrm{d}}$ & .655 & .616 & 11.232045069 & 2.462 \\
\hline a. Predictor variables: (constant) X6, X3, X2, X4, X5, X1 \\
b. Predictor variables: (constant) X3, X2, X4, X5, X1 \\
\multicolumn{6}{l}{ c. Predictor variables: (constant) X2, X4, X5, X1 } \\
\hline
\end{tabular}

e. Explained variable: Y1

TABLE III. Y2 MODEL SUMMARY ${ }^{\mathrm{E}}$

\begin{tabular}{|c|c|c|c|c|c|}
\hline Model & $\boldsymbol{R}$ & $\begin{array}{c}\boldsymbol{R} \\
\text { Square }\end{array}$ & $\begin{array}{c}\text { Adjust the } \\
\boldsymbol{R} \text { Square }\end{array}$ & $\begin{array}{c}\text { Standard } \\
\text { estimation error }\end{array}$ & $\begin{array}{c}\text { Durbin- } \\
\text { Watson }\end{array}$ \\
\hline 1 & $.764^{\mathrm{a}}$ & .583 & .474 & 12.123955683 & \\
\hline 2 & $.764^{\mathrm{b}}$ & .583 & .496 & 11.869284218 & \\
\hline 3 & $.763^{\mathrm{c}}$ & .583 & .516 & 11.634586310 & \\
\hline 4 & $.761^{\mathrm{d}}$ & .579 & .530 & 11.462724836 & \\
\hline 5 & $.757^{\mathrm{e}}$ & .573 & .542 & 11.320580986 & 2.062 \\
\hline
\end{tabular}

TABLE IV. Y3 MODEL SUMMARY ${ }^{\mathrm{E}}$

\begin{tabular}{|c|c|c|c|c|c|}
\hline Model & $\boldsymbol{R}$ & $\begin{array}{c}\boldsymbol{R} \\
\text { Square }\end{array}$ & $\begin{array}{c}\text { Adjust the } \\
\boldsymbol{R} \text { Square }\end{array}$ & $\begin{array}{c}\text { Standard estimation } \\
\text { error }\end{array}$ & $\begin{array}{c}\text { Durbin- } \\
\text { Watson }\end{array}$ \\
\hline 1 & $.733^{\mathrm{a}}$ & .538 & .417 & 8.570862907115 & \\
\hline 2 & $.728^{\mathrm{b}}$ & .530 & .432 & 8.465486467854 & \\
\hline 3 & $.723^{\mathrm{c}}$ & .523 & .447 & 8.352765800410 & \\
\hline 4 & $.712^{\mathrm{d}}$ & .508 & .451 & 8.321575472992 & \\
\hline 5 & $.677^{\mathrm{e}}$ & .458 & .418 & 8.569299039418 & 2.497 \\
\hline
\end{tabular}

From the above R2 and adjust R2, we can see that the model is better. The best fit of the model with Y1 as the explanatory variable is best, which can also explain the influencing factors at the $60 \%$ level in the minimum. Second is Y2 as explained variable model, is followed by Y3 as the explained variable of the model. The D.W values of the three models are within the optimal range of 1.5-2.5. The residuals are independent from the explanatory variables and the model has no collinearity.

B. The "F" test

TABLE V. Y1 ANOVA ${ }^{\mathrm{E}}$

\begin{tabular}{|l|c|c|c|c|c|c|}
\hline \multicolumn{2}{|c|}{ Model } & $\begin{array}{c}\text { sum of } \\
\text { square }\end{array}$ & df & Mean square & F & Sig. \\
\hline \multirow{3}{*}{1} & return & 6515.137 & 6 & 1085.856 & 8.320 & $.000^{\mathrm{a}}$ \\
\cline { 2 - 7 } & Residual & 3001.638 & 23 & 130.506 & & \\
\cline { 2 - 7 } & total & 9516.774 & 29 & & & \\
\hline \multirow{2}{*}{2} & return & 6463.299 & 5 & 1292.660 & 10.160 & $.000^{\mathrm{b}}$ \\
\cline { 2 - 7 } & Residual & 3053.476 & 24 & 127.228 & & \\
\cline { 2 - 7 } & total & 9516.774 & 29 & & & \\
\hline
\end{tabular}

\begin{tabular}{|c|c|c|c|c|c|c|}
\hline \multicolumn{7}{|c|}{ TABLE V. Cont. } \\
\hline \multirow[t]{3}{*}{3} & return & 6389.079 & 4 & 1597.270 & 12.767 & $.000^{\mathrm{c}}$ \\
\hline & Residual & 3127.695 & 25 & 125.108 & & \\
\hline & total & 9516.774 & 29 & & & \\
\hline \multirow[t]{3}{*}{4} & return & 6236.645 & 3 & 2078.882 & 16.478 & $.000^{\mathrm{d}}$ \\
\hline & Residual & 3280.130 & 26 & 126.159 & & \\
\hline & total & 9516.774 & 29 & & & \\
\hline \multicolumn{7}{|c|}{ a. Predictor variables: (constant) X6, X3, X2, X4, X5, X1 } \\
\hline \multicolumn{7}{|c|}{ b. Predictor variables: (constant) X3, X2, X4, X5, X1 } \\
\hline \multicolumn{7}{|c|}{ c. Predictor variables: (constant) X2, X4, X5, X1 } \\
\hline \multicolumn{7}{|c|}{ d. Predictor variables: (constant) X2, X4, X5 } \\
\hline
\end{tabular}

e. Explained variable: $\mathrm{Y} 1$

TABLE VI. Y2 ANOVA ${ }^{\mathrm{E}}$

\begin{tabular}{|c|c|c|c|c|c|c|}
\hline \multicolumn{2}{|c|}{ Model } & $\begin{array}{l}\text { sum of } \\
\text { square }\end{array}$ & $d f$ & $\begin{array}{c}\text { Mean } \\
\text { square }\end{array}$ & $F$ & Sig. \\
\hline \multirow[t]{3}{*}{1} & Return & 4726.392 & 6 & 787.732 & 5.359 & $.001^{\mathrm{a}}$ \\
\hline & Residual & 3380.777 & 23 & 146.990 & & \\
\hline & total & 8107.169 & 29 & & & \\
\hline \multirow[t]{3}{*}{2} & return & 4726.051 & 5 & 945.210 & 6.709 & $.000^{6}$ \\
\hline & Residual & 3381.118 & 24 & 140.880 & & \\
\hline & total & 8107.169 & 29 & & & \\
\hline \multirow[t]{3}{*}{3} & return & 4723.079 & 4 & 1180.770 & 8.723 & $.000^{\mathrm{c}}$ \\
\hline & Residual & 3384.090 & 25 & 135.364 & & \\
\hline & total & 8107.169 & 29 & & & \\
\hline \multirow[t]{3}{*}{4} & return & 4690.923 & 3 & $\begin{array}{l}1563.641 \\
\end{array}$ & 11.900 & $.000^{\mathrm{d}}$ \\
\hline & Residual & 3416.246 & 26 & 131.394 & & \\
\hline & total & 8107.169 & 29 & & & \\
\hline \multirow[t]{3}{*}{5} & return & 4646.969 & 2 & 2323.485 & 18.130 & $.000^{\mathrm{e}}$ \\
\hline & Residual & 3460.200 & 27 & 128.156 & & \\
\hline & total & 8107.169 & 29 & & & \\
\hline \multicolumn{7}{|c|}{ a. Predictor variables: (constant) X6, X3, X2, X4, X5, X1 } \\
\hline \multirow{2}{*}{\multicolumn{7}{|c|}{ b. Predictor variables: (constant) X6, X3, X2, X4, X1 }} \\
\hline \multicolumn{4}{|c|}{ c. Predictor variables: (constant) X6, X3, X2, X4 } & & & \\
\hline \multicolumn{7}{|c|}{ d. Predictor variables: (constant) X6, X2, X4 } \\
\hline \multicolumn{7}{|c|}{ e. Predictor variables: (constant) X2, X4 } \\
\hline
\end{tabular}

e. Explained variable: Y2

TABLE VII. Y3 ANOVA ${ }^{\mathrm{E}}$

\begin{tabular}{|c|c|c|c|c|c|c|}
\hline \multicolumn{2}{|r|}{ Model } & $\begin{array}{l}\text { sum of } \\
\text { square }\end{array}$ & $d f$ & $\begin{array}{c}\text { Mean } \\
\text { square }\end{array}$ & $\boldsymbol{F}$ & Sig. \\
\hline \multirow[t]{3}{*}{1} & Return & 1966.946 & 6 & 327.824 & 4.463 & $.004^{\mathrm{a}}$ \\
\hline & Residual & 1689.573 & 23 & 73.460 & & \\
\hline & total & 3656.519 & 29 & & & \\
\hline \multirow[t]{3}{*}{2} & return & 1936.572 & 5 & 387.314 & 5.405 & $.002^{\mathrm{b}}$ \\
\hline & Residual & 1719.947 & 24 & 71.664 & & \\
\hline & total & 3656.519 & 29 & & & \\
\hline \multirow[t]{3}{*}{3} & return & 1912.301 & 4 & 478.075 & 6.852 & $.001^{\mathrm{c}}$ \\
\hline & Residual & 1744.217 & 25 & 69.769 & & \\
\hline & total & 3656.519 & 29 & & & \\
\hline \multirow[t]{3}{*}{4} & return & 1856.055 & 3 & 618.685 & 8.934 & $.000^{\mathrm{d}}$ \\
\hline & Residual & 1800.464 & 26 & 69.249 & & \\
\hline & total & 3656.519 & 29 & & & \\
\hline \multirow[t]{3}{*}{5} & return & 1673.831 & 2 & 836.915 & 11.397 & $.000^{\mathrm{e}}$ \\
\hline & Residual & 1982.688 & 27 & 73.433 & & \\
\hline & total & 3656.519 & 29 & & & \\
\hline \multicolumn{7}{|c|}{ a. Predictor variables: (constant) X6, X3, X2, X4, X5, X1 } \\
\hline \multicolumn{7}{|c|}{ b. Predictor variables: (constant) X3, X2, X4, X5, X1 } \\
\hline \multicolumn{7}{|c|}{ c. Predictor variables: (constant) X3, X2, X4, X5 } \\
\hline \multicolumn{7}{|c|}{ d. Predictor variables: (constant) X3, X4, X5 } \\
\hline \multicolumn{7}{|c|}{ e. Predictor variables: (constant) $\mathrm{X} 4, \mathrm{X} 5$} \\
\hline
\end{tabular}

In the "F" test, $\mathrm{F}$ value is closer to 10 in general, the effect is the better, and $\mathrm{P}$ value of the test is less than 0.05 , after the above data is filtered, when $\mathrm{Y} 1$ is the explanatory variable, the 
second and third models are tested by "F"; When Y2 is used as the explanatory variable, the third and fourth models pass the test; when Y3 is the explanatory variable, the fourth and fifth models pass the test.

C. The "T" test

TABLE VIII. Y1 COEFFICIENT ${ }^{\mathrm{A}}$

\begin{tabular}{|c|c|c|c|c|c|c|}
\hline & \multirow[t]{2}{*}{ Model } & $\begin{array}{c}\text { Non - } \\
\text { normalized } \\
\text { coefficients }\end{array}$ & & $\begin{array}{c}\text { Standard } \\
\text { coefficient }\end{array}$ & \multirow[t]{2}{*}{$t$} & \multirow[t]{2}{*}{ Sig. } \\
\hline & & B & $\begin{array}{c}\text { Standard } \\
\text { error }\end{array}$ & $\begin{array}{c}\text { trial } \\
\text { version }\end{array}$ & & \\
\hline \multirow{6}{*}{2} & (constant) & 5.811 & 33.512 & & .173 & .864 \\
\hline & $\mathrm{X} 1$ & -.318 & .385 & -.120 & -.827 & .417 \\
\hline & $\mathrm{X} 2$ & -10.097 & 1.973 & -.730 & -5.119 & .000 \\
\hline & X3 & -5.407 & 7.079 & -.100 & -.764 & .452 \\
\hline & $\mathrm{X} 4$ & -.382 & .139 & -.419 & -2.758 & .011 \\
\hline & X5 & 3.282 & 1.384 & .333 & 2.371 & .026 \\
\hline \multirow{5}{*}{3} & (constant) & 10.153 & 32.750 & & .000 & .044 \\
\hline & $\mathrm{X} 1$ & -.404 & .366 & -.152 & -1.104 & -.280 \\
\hline & $\mathrm{X} 2$ & -9.922 & 1.943 & -.717 & -5.107 & .000 \\
\hline & $\mathrm{X} 4$ & -.374 & .137 & -.410 & -2.727 & .012 \\
\hline & $\mathrm{X} 5$ & 2.978 & 1.315 & .302 & 2.265 & .032 \\
\hline
\end{tabular}

TABLE IX. Y2 COEFFICIENT ${ }^{\mathrm{A}}$

\begin{tabular}{|c|c|c|c|c|c|c|}
\hline & \multirow[t]{2}{*}{ Model } & $\begin{array}{c}\text { Non - } \\
\text { normalized } \\
\text { coefficients }\end{array}$ & & $\begin{array}{c}\text { Standard } \\
\text { coefficient }\end{array}$ & \multirow[t]{2}{*}{$t$} & \multirow[t]{2}{*}{ Sig. } \\
\hline & & B & $\begin{array}{c}\text { Standard } \\
\text { error }\end{array}$ & $\begin{array}{c}\text { trial } \\
\text { version }\end{array}$ & & \\
\hline \multirow[t]{5}{*}{3} & (constant) & 61.996 & 7.922 & & 7.826 & .000 \\
\hline & $\mathrm{X} 2$ & -9.344 & 1.889 & -.732 & -4.945 & .000 \\
\hline & X3 & 3.296 & 6.763 & .066 & .487 & .630 \\
\hline & $\mathrm{X} 4$ & -.503 & .128 & -.598 & -3.935 & .001 \\
\hline & $\mathrm{X} 6$ & .060 & .113 & .074 & .535 & .598 \\
\hline \multirow[t]{4}{*}{4} & (constant) & 64.447 & 6.031 & & 10.686 & .000 \\
\hline & $\mathrm{X} 2$ & -9.601 & 1.788 & -.752 & -5.371 & .000 \\
\hline & $\mathrm{X} 4$ & -.516 & .123 & -.613 & -4.179 & .000 \\
\hline & X6 & .064 & .111 & .079 & -.578 & .008 \\
\hline
\end{tabular}

TABLE X. Y3 COEFFICIENT ${ }^{\text {A }}$

\begin{tabular}{|c|c|c|c|c|c|c|}
\hline & \multirow[t]{2}{*}{ Model } & $\begin{array}{c}\text { Non - } \\
\text { normalized } \\
\text { coefficients }\end{array}$ & & $\begin{array}{c}\text { Standard } \\
\text { coefficient }\end{array}$ & \multirow[t]{2}{*}{$t$} & \multirow[t]{2}{*}{ Sig. } \\
\hline & & B & $\begin{array}{c}\text { Standard } \\
\text { error }\end{array}$ & $\begin{array}{c}\text { trial } \\
\text { version }\end{array}$ & & \\
\hline \multirow[t]{4}{*}{4} & (constant) & -58.726 & 20.459 & & -2.870 & .008 \\
\hline & $\mathrm{X} 3$ & -8.017 & 4.942 & -.240 & -1.622 & .117 \\
\hline & $\mathrm{X} 4$ & .207 & .084 & .366 & 2.462 & .021 \\
\hline & $\mathrm{X} 5$ & 3.070 & .940 & .502 & 3.266 & .003 \\
\hline \multirow[t]{3}{*}{5} & (constant) & -51.590 & 20.575 & & -2.507 & .018 \\
\hline & $\mathrm{X} 4$ & .238 & .084 & .422 & 2.836 & .009 \\
\hline & $\mathrm{X} 5$ & 2.545 & .909 & .416 & 2.800 & .009 \\
\hline
\end{tabular}

That $\mathrm{P}$ value of $\mathrm{T}$ test is greater than 0.05 shows that there is a collinear relationship. After the above table data screening, It passes the test that the model three in the case of Y1 to be interpreted variables, When Y2 is the explanatory variable, the model four passes the test; when Y3 is the explanatory variable, the model five passes the test. Thus, the optimal capital structure model obtained by the "backward" regression method is as follows:

$$
\begin{gathered}
\mathrm{Y}_{1}=-0.404 \chi_{1}-9.922 \chi_{2}-0.374 \chi_{3}+2.978 \chi_{4}+10.153 \\
\mathrm{Y}_{2}=-9.601 \chi_{2}-0.516 \chi_{4}+0.064 \chi_{6}+64.447 \\
\mathrm{Y}_{3}=0.238 \chi_{4}+2.545 \chi_{5}-51.590
\end{gathered}
$$

\section{CONCLUSION}

The profitability of listed companies along the "OBOR" is strong, so the accumulation of internal surplus leads to reduce the external financing demand, that is, listed companies along the "OBOR" have more first internal financing to carry out, which the high current ratio one of these are likely to take liquidity assets as a source of investment funds, and listed companies along the "OBOR" use more current assets as short-term financing than outbound debt financing generally. Studies have shown that most of A-share listed companies in China prefer foreign financing, especially equity financing, this does not conform to the order of endogenous financing-bond financingequity financing in Western advanced order financing theory, However, due to the listed companies along the "OBOR" are mostly the port and iron construction and other large infrastructure companies, which have rich internal accumulation and national policy support, so that the capital structure of such listed companies prefer to adopt endogenous financing, and the financing order is in line with the optimal order financing theory. From the results of the study, "OBOR" listed companies exist idle assets and the use of inadequate assets, which reduces the financial security of debt financing and asset income, so that the company's total asset turnover rate is not high. The stronger the collateral of fixed assets gets, the more easily the company obtains long-term liabilities. And compared to the repayment pressure for current debt, "OBOR" listed companies are more dependent on long-term liabilities in the expansion of the scale. "OBOR" listed companies with high growth are in the expansion phase generally, which have a good reputation level and credit guarantee capacity, relying on debt financing to meet the expansion of capital needs in general.

\section{REFERENCES}

[1] Modigliani F.,Miller M.. The cost of capital, corporation finance and the theory of investment [J]. American Economic Review, 1958,(2).

[2] S Myers,N Majluf. Corporate Financing and Investment when Firms Have Information Shareholders Do Not Have [J].Journal of Financial Economics,1984,(13):187-222.

[3] XIAO Zuo-ping. Study on the Choice of Capital Structure of Listed Companies and Empirical Study [J]. Securities Market Newspaper. 2004 (9): 25-30.(in Chinese)

[4] Charalambakis E.C. Psychoyios D. What Do We Know about Capital Structure? Revisiting the Impact of Debt Ratios on Some Firm-Specific Factors[J].Applied Financial Economics,2012,22(19-21):1727-1742

[5] XING Tian-cai, YUAN Ye. Experimental Study on Determinants of Capital Structure for Listed Companies in China [J]. Macroeconomic Research, 2013, (2): 34-40.

[6] Song Chuan-fen. Effects of Capital Structure on Listed Companies' Control Rights and Countermeasures [J] .Chinese Journal of Business Administration, 2015, (24): 73-75. 